\title{
UNIVERSITYOF
}

FORWARD

THINKING

WESTMINSTER用

WestminsterResearch

http://www.westminster.ac.uk/westminsterresearch

Notes on Photography and Cultural Translation

Soutter, L.

This is an accepted manuscript of an article published by Taylor \& Francis in Photographies, 11 (2-3), pp. 329-338.

The final definitive version is available online:

https://dx.doi.org/10.1080/17540763.2018.1445018

(c) 2018 Taylor \& Francis

The WestminsterResearch online digital archive at the University of Westminster aims to make the research output of the University available to a wider audience. Copyright and Moral Rights remain with the authors and/or copyright owners.

Whilst further distribution of specific materials from within this archive is forbidden, you may freely distribute the URL of WestminsterResearch: ((http://westminsterresearch.wmin.ac.uk/).

In case of abuse or copyright appearing without permission e-mail repository@westminster.ac.uk 


\title{
Notes on Photography and Cultural Translation \\ Dr Lucy Soutter \\ University of Westminster
}

\begin{abstract}
The essay explores issues in the cultural translation of photographic images and ideas, particularly between East and West. Audiences and institutions continue to fall prey to the persistent notion that photography should demonstrate aspects of national identity. This foregrounding of cultural difference inhibits more layered interpretations. The work of cultural translation involves the movement of subjects rather than objects, with dialogue and personal experience essential to understanding. Drawing on the author's experience working in China, the essay looks to Homi K. Bhabha, Jacques Rancière and 1960s critical pedagogy for constructive terms to shift the perspective of photographic education.
\end{abstract}




\section{Notes on Photography and Cultural Translation}

\section{A Margin of Untranslatability}

In 2016, my monograph about contemporary photography, Why Art

Photography? was translated into Chinese. A British friend asked me, "Which

Chinese characters did your translator use for the word 'photography' in the

title of your book? You do realise that there are several possibilities, don't you, with quite different connotations?" I felt a sudden panic, as I was brought faceto-face with fundamental facts about the translation of text from one language to another. Even when made with the greatest possible fluency and skill, a translation will always change the meaning of a text in many ways, and not all words or concepts will be directly translatable. Words rarely have an exact equivalence to those in another language, and the target culture into which the text is translated will also have its own modes of interpretation. Despite the skill of the translator, the translation of my book is undoubtedly a different text to the one I wrote. Yet who is to say that this new book is any worse or perhaps better than the original? Without years of study and living in China, I cannot know what new propositions are produced by the translator's choice of characters, what new dialogues it may open. Certainly, for the purposes of intercultural discussion of photography, it is much better to have translated the book than not.

This story raises some key issues at the heart of international discussions of photography. How can we discuss the similarities and differences in our understanding of photographic images and ideas when we are using different words, concepts and traditions to speak and write about them? Of course, one can spend a lifetime becoming immersed in the complexities of another's culture, and gradually develop understanding. Many scholars devote their careers to these issues, and their work gradually shifts the cultural landscape. International photographers and writers with multiple fluencies are essential to this endeavour. The figure of the translator is key as an agent who can work meaningfully across boundaries. But for those of us whose day-to-day teaching takes place in Western photography programmes, the questions remain: how can we better understand this work of cultural translation? How can we help it along?

These questions are not merely academic. A growing proportion of photography students in Europe and the United States are from overseas, increasingly from the Pacific Rim. It is an ongoing task to consider what to teach on photography courses and how to teach it. For the question is not merely what do you need to know to be a photographer today, but what do you need to know to be a global photographer, moving between contexts and cultures?

This essay is a brief introduction to some of the issues in the cultural translation of photographic images and ideas, particularly between East and West. ${ }^{1}$ From the start, I acknowledge that my perspective is Western, as I have been educated and raised in the United States and Britain. The small but not inconsequential gap between these two Anglophone cultures has informed my interest in the topic. My own principal experience of translation 
with a non-western photographic culture has been in relation to working experiences I have had in China over the past couple of years. I hope that my observations and proposals, rooted in this experience, will open up some points of broader concern. I am not a translator myself, though my role as a photography historian, theorist and critic involves bridging different discourses, and interpreting the work of one set of cultural workers so that it can be understood by another. In this essay, I draw on academic disciplines that address issues of cultural exchange, in particular philosophy, postcolonial studies and translation studies in order to consider their usefulness to the current situation. Above all, I hope to contribute to a dialogue that will extend into future international photographic education, networks and cultures.

\section{The Global Contemporary}

First, I will provide a very abbreviated summary of the situation to which this essay responds. The story is familiar, but bears repeating. The $21^{\text {st }}$ century has seen a rapid, dramatic internationalization of photography, in tandem with the globalisation of art-and of labour-more broadly. Those of us who work in the photography world are now very familiar with overseas students, globetrotting photographers, international curators, cosmopolitan collectors and a packed calendar of global photography exhibitions, fairs, festivals and auctions. As a positive contribution to mutual understanding, there are more and more photography books being translated from one language to another, and more than ever being published internationally about the photography of non-western cultures. I might mention two excellent books on the photography of China and Southeast Asia published in English in recent years: Zooming in: Histories of Photography in China by Wu Hung, a Chinese-born scholar working in the United States, and Photography in Southeast Asia: A Survey by Singapore-based photographer and writer Zhuang Wubin. ${ }^{2}$

Yet in other ways, cross-cultural understanding has stalled. British art critic J.J. Charlesworth sums up the problem in his 2012 article, "Global versus Local." 3 He argues that the contemporary art world is now so confident that it has achieved a universal understanding, what he calls an art world "Esperanto," that local differences and concerns may be flattened and ongoing failures of translation heightened.

At the risk of oversimplifying, the western narrative for globalisation in the Anglo-American photography world has been one of "inclusion," in which images from "outside" the largely European and American tradition have been gradually brought in to sit alongside the familiar western images, where they can be compared and contrasted with a view towards appreciating them, usually for their difference: the unfamiliar and frequently exotic aspects of their content or form. For decades, there have been varying degrees of awareness that this approach is problematic and inadequate, but in practice, it remains very common. Charlesworth describes how "cultural difference" can become a "globally recognized product" that circulates as a commodity within the global art market. 
For example, some of the earliest galleries to bring Chinese photography to commercial photography fairs like Paris Photo in the late 1990s and early 2000s specialised in works that engage very explicitly with aspects of traditional Chinese art, featuring distinctively Chinese landscape compositions, visual references to calligraphy, hanging scrolls, folding screens, etc. ${ }^{4}$ As with the decorative Chinese porcelain that has been exported to the West since the $17^{\text {th }}$ century, these works may easily be admired and consumed for their "Chineseness." A western viewer does not have to try very hard to understand such images once they are categorized in this limited way. They can enjoy the works for their beauty and exoticism without attempting to understand their deeper art historical, literary or philosophical context. I am using Chinese photography as my example, but could easily find related examples to do with photography from Nigeria, Japan, India, Saudi Arabia, Mexico, etc. I would like to underline that I am in no way undermining the aesthetic merit, conceptual complexity or political engagement of such works, I am merely pointing out that the western reception of them has frequently flattened the meanings they might have held in the context of their making. The market can be expected to reduce art works to commodities, but this problematic extends beyond the market.

To provide a supporting anecdote, I once visited the London home of an eminent photography collector, an individual with a place on the acquisitions committee of several major museums. She had a large number of very striking Chinese works in her collection. Each photograph foregrounded its country of origin with explicit reference to Chinese identity, landscape or culture. While I admired these works, they led me to ask the collector a question: "Would you ever purchase a Chinese photograph that could not immediately be visually identified [by a Westerner] as Chinese?" To which her answer was "What would be the point of that?" This comment reinforces Juliet Hacking's observation that there is a widespread expectation, even among sophisticated audiences, that photographs should demonstrate aspects of national cultural identity. ${ }^{5}$ Western viewers do not require this of western photography, so why should they demand it of Chinese photography? What other kinds of meaning get pushed to the side when nationality is foregrounded to this extent?

The tendency to focus on national identity in photography also applies to Western photography exported to the East. To provide another example from my own experience, in 2015 I was commissioned to write a catalogue essay for the first survey of British photography to tour China: "Work, Rest and Play: British Photography from the 1960s to Today." This exhibition was curated by The Photographers Gallery, London, in order to showcase the quality and range of British photography. As the title suggests, the show was also intended to show Chinese viewers something about life in Britain over the last 50 years, to say, "This is what we are like. This is who we are." The photography practices included were very eclectic, ranging from commercial magazine portraits of celebrities to documentary reportage of race riots, from staged narrative photographs to conceptual art projects. In short, this mixedup collection of works would not have made much sense to British viewers. It was a strange task, especially as a writer born in the U.S.A., to write an essay 
arguing that these pictures represent aspects of what it means to be British. Many of the photographic projects in the show were ones that I had lectured or written about before-but never through the interpretive lens of "Britishness"! Of course, I also tried to squeeze other ideas into my short essay, but was frustrated that I had to fit them in around the theme of national identity.

To explore this using the terms of post-colonial studies, there is still a strong tendency - theorized by Edward Said as "Orientalism"-to look to cultures perceived as different or "other" to offer an exciting, illuminating jolt of difference, whether or not that is what the photographers of that culture desire or intend. In the last decade, there has been a shift in the discourse of globalization, a new narrative of convergence and homogenization. This perceived trend towards "becoming-the-same," which has been questioned by sinologists including Daniel Vukovich, can be just as misleading as Orientalism, as it starts from the same assumption, that one's own way of looking at things is the norm against which other cultures should be measured. 6 "Oh look—they are becoming just like us!" the viewer might think, and again an opportunity for deeper understanding has been missed.

\section{Some Notes on Cultural Translation and Pedagogy}

And now I turn to some ideas that might be productive in reconsidering the situation. The hybrid disciplines of translation studies and cultural translation are particularly productive for this discussion, drawing as they do on cultural studies, social anthropology, actor-network-theory (also known as "translation sociology"), literary theory, philosophy and linguistics. ${ }^{7}$

Following Homi K. Bhabha, I would like to emphasize that cultural translation is led more by the movement of subjects than objects, of people rather than images, texts or artefacts. ${ }^{8}$ Photographic images, with their illusion of transparent meaning, are very easy to strip from their original context and read through the lens of the culture in which they are viewed. Reading texts about a photographic culture can round out the picture. Understanding deepens most effectively through dialogue and personal experience. Books and the internet have their merits, but for this work to accelerate, actual people must make actual journeys.

For me, travelling to the Lianzhou Foto Festival for the first time in 2015 and again in 2016 was an education and an inspiration. I saw work by dozens of Chinese (and other Pacific Rim) photographers, much of which had never been exhibited outside of China. I was immediately struck to see work in a far broader range of styles, with much more diverse subject matter than I expected. As part of these visits, I held a number of portfolio reviews through an interpreter. Removed from my own ordinary context, and communicating in an unfamiliar way, I was brought into confrontation with the fact that my terms of interpretation were rather different than those of the photographers. Some questions that struck me as straightforward were met by incomprehension, others seemed to open up areas of discussion that it might not have occurred to me to pursue. The presence of an interpreter made it possible for photographers to nuance their explanations beyond the limits of their own 
English vocabulary. The process also encouraged me to listen with fresh ears, straining for subtleties of expression.

This experience has shifted the way that I interact with Chinese photography students when I encounter them in teaching situations in the West. I have begun to ask new questions about what standards the students are applying to themselves. In what ways does the Western art school framework for interpretation fit or not fit their work? How else might they like to discuss it? Recent scholarship debunks the notion that Chinese students are less welltrained for critical thinking than their western counterparts. ${ }^{9}$ On the contrary, they may arrive at university with more advanced critical skills, but with obstacles to overcome in terms of language and expectations. ${ }^{10} \mathrm{It}$ is surely our task as educators to meet them part way, with a kind of interpretive hospitality, in which we are willing to question our own terms of reference as well as theirs. ${ }^{11}$

In their writing on the ethnography of science, French theorists Michel Callon and Bruno Latour propose that the act of translation creates new networks and power relationships. ${ }^{12}$ In my own experience, I have realised that when I am addressing a photography student from a culture different from my own, there will be some areas in which I am "the expert" with knowledge and understanding to share, but that there will be other areas in which it is important for me to admit my ignorance in order to allow students to make their own discoveries, and sometimes to teach me.

French philosopher Jacques Rancière has celebrated the notion of the "ignorant schoolmaster" whose willingness to admit his own lack of mastery allows him to teach without knowledge, even in a language not his own. ${ }^{13}$ Rancière raises the possibility that a shifted power relationship between student and teacher may lead to an "intellectual emancipation" on both sides. I am not saying that students have all the answers-especially if they come from a place in which practitioners have limited access to their own cultural history-especially if they have not had an opportunity to pursue their subject in an intense, critically engaged way. But my own experiences of cultural translation have opened my eyes to the extent that strategies of meaning differ between cultures. My work with international students has become much more interesting as I have learned to see myself as also a student.

Am I talking about "letting go" of a western photographic canon of images and texts? There have been a number of scholarly works in the past few years describing a gradual collapse of Western certainties about art and the art world. Peter Osborne has described contemporary art as a convenient fiction, a notion that flattens various times and locations into a single field. ${ }^{14}$ Pamela Lee has described the way that globalization produces a plural, unstable, discontinuous art world in which everything is equally available for consumption. ${ }^{15}$ And indeed, many of the talks at the 2017 Photographies conference neglected the "classics" of photography theory, in favour of new methodologies and new bibliographies as appropriate to the inquiry at hand. In these conditions, perhaps it is actually productive that students are arriving 
on photography courses with totally disparate backgrounds, without the lexicon of shared images or texts that we expected until very recently?

One perfectly reasonable response to this turn of affairs by western photography educators would be to fall back on a canon of critical theory texts - the ones that seemed so perfect for navigating the intellectual and political climate of the 1980s, 90 s and early 2000s. But many of us are letting go of the assumption that our job as photographic educators is to present a "host" culture to which our students will gradually become acculturated. I would like to find more ways to work with our students to build a third cultural space, a new home that challenges intercultural boundaries. This may involve a constructive deterritorialization, a letting go of some assumptions about who we are, and which intellectual territory belongs to us. ${ }^{16}$ In my own teaching, I am increasingly interested in drawing images, texts, themes and questions from the students themselves, and trying to combine them with elements from a canon that I continue to value. The notion of students as co-creators of knowledge rather than passive recipients is nothing new. It emerged in the critical pedagogy of the 1960s, in texts such as Paulo Freire's 1968 Pedagogy of the Oppressed, and Neil Postman and Charles Weingartner's Teaching as a Subversive Activity. ${ }^{17}$ Feminist theorists further extended the challenge to educational hierarchies, with bell hooks, for example, arguing in her 1994 Teaching to Transgress that students-and educators-must learn to "transgress" the boundaries of race, gender and class in pursuit of a more engaged pedagogy. ${ }^{18}$ Within the current university culture of learning outcomes and assessment criteria it can be difficult for educators to retain the spirit of open-minded inquiry espoused by such educational radicals, but it is needed as much as ever.

\section{Confusion, Awkwardness and Failure}

My own introduction to these issues has included many moments of confusion, awkwardness and failure. After my first trip to Lianzhou Foto, I had become so eager for dialogue that I asked to moderate the following year's festival symposium on the translation of photographic images and ideas. My proposal was accepted, and culminated in a 2-day event in November 2016: "Concept of Photography: Translating Visual Cultures in the Context of Globalization." I had anticipated that the event would raise more questions than it answered, and indeed it did.

As the previous year's symposium had involved simultaneous translation in several languages, I had envisioned a lively dialogue. However, aside from my own talk and one by photographer Sunil Gupta, the 2-day event was conducted in Chinese without translation. This made the majority of talks inaccessible to most of the festival's international visitors, including me. I stayed the full 2 days to make what I could of my experience as linguistic outsider. Many of the images projected by the Chinese speakers were familiar to me (including Robert Demachy, Paul Strand, Robert Rauschenberg and Barbara Kruger), as were many of the names invoked (John Tagg, Victor Burgin and Allan Sekula got mentions, as did Clement Greenberg, André Bazin and John Szarkowski), but I missed most of the intellectual content. For a couple of the talks I was lucky enough to be sitting next to an off-duty 
Chinese-English translator, and prodded him for whispered highlights. One eminent photography critic explained that the Chinese had begun to engage seriously with photographic ideas when Western photography texts has first been translated into Chinese in the 1980s. The cultural context of these texts was initially so alien that misunderstandings were rife. Problems persist in particular around the choice of characters to translate specialist theoretical terms. The critic noted, for example, that in the 2007 Chinese translation of Guy Debord's Society of the Spectacle, the character used for "spectacle" is the one commonly used for "landscape," short-circuiting Debord's central concept entirely. I was especially interested to learn (if I understood correctly) the critic describing pictorialism, modernism and postmodernism as having equal validity in contemporary Chinese photography, in large part because all eras of historical photographic production came into visibility at once post1988.

Another moment of fascination for me was when a Chinese art historian explained that Western photography is particularly concerned with presence, absence and ephemerality because Christians believe in the real presence of the Holy Spirit and in the transubstantiation of bread into the body of Christ in Holy Communion. While this theory is not often encountered in Western photographic criticism, it seems a perfectly reasonable projection in relation to the kinds of cultural assumptions that Western critics and historians routinely make about Asian photography.

The event had a surreal postscript. A few months after my trip to Lianzhou, I learned that the 2016 Chinese translation of my book had been withdrawn from circulation. Ironically, in light of the current discussion, one of the issues at stake was the use of the same character to translate the English words "object" and "subject," a choice that greatly undermined the book's discussion of photographic objectivity. I gather the translation has since been revised and re-issued. I refuse to be too discouraged by any of these moments of breakdown in communication, because they are each revealing in their own way, and each had something to teach me.

As a positive outcome of the symposium, one Taiwanese photographer came up to me after my presentation (an early version of this paper) and said, "Yes, yes! You're on to something." He told me that he had done a BA in Photography in the U.S.A. where he had felt constantly talked down to, patronised and belittled. But that in his MA in the Netherlands, he had experienced a far less hierarchical educational model and had felt his cultural background was valued as part of the group discussion. This is not to argue that one country's educational system is universally more hierarchical than the other's - it is also possible that some of this difference lay in the difference between one institution and another, or even one instructor and another. The point I took to heart was that a more hospitable educational culture felt far more constructive to an international student.

There are many competing theories of translation. ${ }^{19}$ Against the traditional view that the translator should simply seek the best word-for-word equivalence to reproduces the meaning of the original text in the target 
language, there are less literal theories that emphasize the actual use to which the translated text is going to be put, and theories that emphasize translation as a form of conscious and deliberate re-writing. When produced with the intention of mediating the gap between cultures, such translation might be referred to as multicultural or intercultural. How do these theories come to bear in the translation of photographs and of photographic ideas? Because they are visual signs, photographs are often perceived to be a "universal language" that offer their content freely to a viewer from any cultural context. Of course, specialists in the field know that this is a very naive view, which fails to account for the layers of meaning embedded in images and in the contexts in which they circulate. Photographs frequently require explanation-itself a form of "translation"-even for viewers within the same culture in which they were produced. Within the current conditions of globalization, we need people trained in visual literacy and interpretive sophistication, not only to enjoy a rich culture of art and entertainment, but also to communicate effectively with one another. Photographic education can provide excellent training in these skills.

The cultural translation of photography develops through photographers (including students), curators and scholars developing multiple fluencies and hybrid perspectives. ${ }^{20}$ Photographic education plays a key role, especially where educators are willing to relinquish existing power relationships in favour of alternative models, such as Rancière's "ignorant schoolmaster," or hooks' "teaching to transgress" or where groups are able to build their own intellectual culture, combining images and texts from East and West with those that emerge from the interests of the group. The dominance of theories grounded in western art history and critical theory still begs to be disrupted. Homi Bhabha describes cultural translation as a process, rather than a product. And the process is not always easy, or comfortable. For photography education to continue to be relevant and in order for new paradigms to evolve beyond the powerful pull of the photography market and its appetite for the exotic, it is necessary for photographers, curators, educators and scholars to embrace a margin of questioning, awkwardness and unknowing.

1. Of course, the very terms "East" and "West" deserve scrutiny, and are increasingly challenged by scholars as artificial constructs. See, for example, Hobson, The Eastern Origins of Western Civilization.

2. Wu, Zooming in, and Zhuang, Photography in Southeast Asia.

3. Charlesworth, "Global vs. Local."

4. Paris Photo was first held in 1997.

5. Hacking, "Lost in Translation."

6. Vukovich, China and Orientalism.

7. I am grateful to Alexa Alfer for correspondence underlining the fact that translation studies extends beyond the purely linguistic to encompass many of the same transdisciplinary concerns addressed by cultural translation.

8. Bhabha, The Location of Culture.

9. Henández, "Study Finds Chinese Students Excel"

10. Tian and Low, "Critical thinking and Chinese university students."

11. I am drawing here on Paul Ricœur's idea of "linguistic hospitality," a delicate balancing in which translators acknowledges the need to reflect on their own language while being receptive to another. See Ricœur, On Translation. My understanding of Ricœur was greatly enhanced by Sarah Maitland's presentation, "Distanciation and the Translator." 
12. Akrich, Callon and Latour, Sociologie de la Traduction.

13. Rancière, The Ignorant Schoolmaster.

14. Osborne, Anywhere or Not at All.

15. Lee, Forgetting the Art World.

16. Stuart Elden provides a thoughtful overview of competing definitions of deterritorialization in his essay, "Missing the Point."

17. Freire, Pedagogy of the Oppressed; Postman and Weingartner, Teaching as a

Subversive Activity.

18. hooks, Teaching to Transgress.

19. See, for example, Pym, Exploring Translation Theories.

20. Irit Rogoff has written of the need for "new vocabulary" to discuss art works that emerge from new forms of global encounter. See Rogoff, "Geo-Cultures: Circuits of Arts and Globalizations."

Bibliography

Akrich, Madeleine, Michel Callon and Bruno Latour. Sociologie de la Traduction. Paris: Presses des Mines, 2006.

Bhabha, Homi K. The Location of Culture. Abingdon: Routledge, 1994.

Charlesworth, J.J. "Global vs. Local." Art Review (November 2013).

https://artreview.com/features/november 2013 feature global versus local by ii charlesworth 1/.

Elden, Stuart. "Missing the Point: Globalization, deterritorialization and the space of the world." Transactions of the Institute of British Geographers 30, no. 1 (March 2005): 8-19.

Freire, Paulo. Pedagogy of the Oppressed. Translated by Myra Ramos. New York: Herder and Herder, 1970.

Hacking, Juliet. "Lost in Translation: Interpreting Chinese Photography."

Photographies 8, no. 2 (September 2015): 191-210.

Henández, Javier C. "Study Finds Chinese Students Excel in Critical Thinking. Until College." The New York Times, (20 July 2016).

https://www.nytimes.com/2016/07/31/world/asia/china-college-educationquality.html.

Hobson, John M. The Eastern Origins of Western Civilization. London: Cambridge University Press, 2004.

hooks, bell. Teaching to Transgress: Education as the Practice of Freedom. New York: Routledge, 1994.

Maitland, Sarah. "Distanciation and the Translator." Paper presented at the University of Westminster Modern Languages and Cultures Research

Seminar, January 31, 2018.

Osborne, Peter. Anywhere or Not at All: Philosophy of Contemporary Art. London: Verso, 2013.

Postman, Neil, and Charles Weingartner. Teaching as a Subversive Activity. New York: Dell, 1969.

Pym, Anthony. Exploring Translation Theories. Abingdon: Routledge, 2014. Rancière, Jacques. The Ignorant Schoolmaster. Translated by Kristin Ross. San Francisco: Stanford University Press, 1991.

Ricœur, Paul. On Translation. Translated by Eileen Brennan. Abingdon:

Routledge, 2006.

Rogoff, Irit. "Geo-Cultures: Circuits of Arts and Globalizations." open! Platform for Art, Culture and the Public Domain.

http://www.onlineopen.org/article.php?id=53. 
Tian, Jing, and Graham David Low. "Critical thinking and Chinese university students: a review of the evidence." Language, Culture and Curriculum 24 no. 1 (February, 2011): 61-76.

Vukovich, Daniel. China and Orientalism: Western Knowledge Production and the P.R.C. Abingdon: Routledge, 2012.

Wu, Hung. Zooming in: Histories of Photography in China. London: Reaktion, 2016.

Lee, Pamela. Forgetting the Art World. Cambridge, MA: MIT Press, 2012. Zhuang, Wubin. Photography in Southeast Asia: A Survey. Singapore: NUS Press. 